\title{
Corporate Reputation and Performance: A Legitimacy Perspective
}

\author{
Honggui G. Li, Zhongwei W. Chen, Guoxin X. Ma
}

\begin{abstract}
A B S T R A C T
Objective: The objective of this paper is to investigate the mediating role of innovation legitimacy between corporate reputation and enterprise growth.

Research Design \& Methods: Four hypotheses were formulated and tested in to achieve the research objective. We collected data from 191 enterprises in 16 provinces in China. In total, 300 enterprises were selected to participate in this study. Descriptive analyses showed that the valid data covered a wide range of samples in terms of enterprise types and sizes, industries, market positions and years of establishment. The data was analysed by regression analysis.
\end{abstract}

Findings: The results of this research suggest that corporate reputation has significant positive relationship with enterprise growth. This positive relationship was found through all pathways tested. This means that brand image, social responsibility, innovation capability and staff quality are all important to enterprise growth. Similar effects were found for innovation legitimacy on enterprise growth, indicating that legitimacy is an important theoretical perspective in understanding how businesses could develop in various important aspects.

Implications \& Recommendations: Legitimacy is an important theoretical framework in understanding the complex relationships between corporate reputation and enterprise growth, especially from the innovation perspective. Future research may look into these results in other contexts and further pursue the legitimacy perspective in understanding corporate reputation and enterprise growth.

Contribution \& Value Added: This research contributes towards understanding the mediating effects of innovation legitimacy between corporate reputation and performance, especially in Chinese context.

\begin{tabular}{lll}
\hline Article type: & research paper \\
Keywords: & $\begin{array}{l}\text { corporate reputation; enterprise growth; legitimacy; innovation; } \\
\text { China }\end{array}$ \\
JEL codes: & L26, O53 & \\
\hline Received: 30 January 2016 & Revised: 10 June $2016 \quad$ Accepted: 11 August 2016 \\
\hline
\end{tabular}

\section{Suggested citation:}

Li, H.G., Chen, Z.W., \& Ma, G.X. (2016). Corporate Reputation and Performance: A Legitimacy Perspective. Entrepreneurial Business and Economics Review, 4(3), 181-193, DOI: http://dx.doi.org/10.15678/EBER.2016.040313 


\section{INTRODUCTION}

Being argued to be the most valuable organisational asset (Gibson, Gonzales \& Castanon, 2006) and intangible resource (Hall, 1993), corporate reputation has long been acknowledged as a significant source of sustained competitive advantage (Fombrun \& Shanley, 1990). Not surprisingly, research evidence shows that corporate reputation has significant implications on a variety of organisational and business issues including costs (Deephouse, 2000) and pricing policies (Rindova, Williamson, Petkova \& Sever, 2005). It has been argued that corporate reputation also has long-term effects on firms (Fang, 2005). Amongst these scholarly efforts, positive links between corporate reputation and firm performance have been established (Fombrun \& Shanley, 1990).

Concurrent with the growth of empirical evidence showing positive links between corporate reputation and firm performance that has been spanning over a quarter century, the existing research is largely focused on the theoretical framework of the resource-based view (RBV) (Barney, 1991). While useful, this emphasis may fail to explain the complex relationships between the two variables (Carmeli \& Tishler, 2005). This paper seeks to contribute to our understanding of the complexity of relationships between corporate reputation and firm performance through the lens of legitimacy (Suchman, 1995). Specifically, the objective of this study is to investigate the potential mediating role of innovation legitimacy between corporate reputation and enterprise growth. By analysing quantitative data collected from Chinese enterprises, our findings suggest that innovation legitimacy has a significant mediating effect on the positive correlations between corporate reputation and enterprise growth.

The remaining of this article is structured as follows. First, we review literature to show how innovation legitimacy may act as a mediator between different dimensions of corporate reputation and enterprise growth. We construct a conceptual model to illustrate the hypothesised pathways between variables based on our review of relevant research. In the next section, we explain our sampling and data collection procedures as well as how these data were analysed by statistical tools. Detailed analyses and results will be demonstrated next before we will discuss these results and the implications. We then discuss the limitations of this research and point out future research directions. We conclude our research in the final section of this article.

\section{LITERATURE REVIEW}

This section reviews research on legitimacy, corporate reputation and firm performance to derive hypotheses for this study. We begin by reviewing literature on corporate performance.

\section{Corporate Reputation}

Corporate reputation, for this study, is broadly understood as a perceptual representation of an organisation regarding a set of its attributes associated with or inferred from the organisation's past activities, referring to both perceived identity and image of an organisation. While organisational identity has an internal focus and organisational image usually refers to internal audiences, corporate reputation tends to involve percep- 
tions of all stakeholders (Walker, 2010). The most studied theoretical perspective within corporate reputation literature is RBV. Studies from the RBV perspective view corporate reputation as an unreplaceable resource of the company that may lead to sustained competitive advantages and examine how such effects are resulted (Flanagan \& O'Shaughnessy, 2005), for example, through uncertainty reduction by signalling product quality (Rindova et al., 2005). Another frequently used theory in the literature is signalling theory, focusing on strategic organisational signals that are perceived and decoded by the stakeholders. For example, Basdeo, Smith, Grimm, Rindova and Derfus (2006) applied corporate reputation into explaining how stakeholders may view a company's strategic choices as signals sent by the company to form impressions. From this perspective, social perceptions may influence corporate reputation (Turban \& Greening, 1997). Many scholars have studied corporate reputation from other theoretical perspectives including game theory (Milgrom \& Roberts, 1982), stakeholder theory (Cable \& Graham, 2000), social identity theory (Turban \& Greening, 1997) and mass communication theory (Deephouse, 2000). Within a number of theories studied, a predominant theoretical perspective is institutional theory whereby the focus is on institutional contexts and reputation building. Institutional theory is used in the literature to investigate how organisations can gain socio-cultural legitimacy to enhance organisational reputation by exploring their institutional contexts. From this perspective, environmental contexts of an organisation are crucial to its reputation in order to legitimate its activities. This study extends the literature by putting the spotlight on organisational innovation legitimacy.

\section{Organisational Innovation Legitimacy}

Legitimacy may be broadly understood as a generalised perception that an entity, and/or its actions, is justified according to a societal culture. As an important source of organisational resources, legitimacy enhances the stability of organisational innovation because organisational innovation that are perceived to be appropriate and desirable tend to receive more resources from stakeholders (Parsons, 1960) and have less collective action problems (Olson, 1965). Since legitimacy involves a collective rationale explaining the actions and purposes of an organisation (Jepperson, 1991), legitimate organisations are likely to be more comprehensible and thus ready to sustain.

Within the existing literature, legitimacy has been studied from different perspectives. For example, Dowling and Pfeffer (1975) suggest that organisational actors may support a company policy based on the policy's expected value to them, implying a kind of exchange legitimacy. Organisations may also possess dispositional legitimacy, evidenced by the fact that organisational actors often perceive, or act as though that, organisations have personalities including interests, styles and tastes (Pfeffer, 1981). From an evaluative angle, moral legitimacy reflects a normative assessment of organisational actions (Aldrich \& Fiol, 1994), indicating judgements on whether the organisation is 'doing the right thing'.

From a consequential perspective, Scott and Meyer (1991) tested organisational consequential measures such as automobile emission standards and hospital mortality rates to test organisational effectiveness. Structurally, organisations may be viewed as categorically legitimate whereby organisational legitimacy resides in its morally favoured structural characteristics (Zucker, 1986). Individually, organisational legitimacy may rest 
on the leaders in the organisation, albeit such personal legitimacy may be more transitional and idiosyncratic (Zucker, 1986). Finally, legitimacy may be studied on a cognitive level, indicating taken-for-granted assumptions and beliefs about the organisations and their activities (Jepperson, 1991).

The studies of organisational legitimacy dynamics focusing on cognition are different from legitimacy based on evaluation or interests, as cognitive legitimacy does not involve a positive or negative evaluation of organisations (Aldrich \& Fiol, 1994). Grounded on this cognitive angle, this paper extends the literature by studying legitimacy based on perceptions of the level of legitimacy on organisational innovations. The next section reviews literature on corporate performance.

\section{Corporate Performance}

In this study, we examine corporate performance through the lens of enterprise growth. Sustained growth of a corporation is an understandable organisational objective that guides organisational strategies and management practices. Although the goal to grow may appear more important for relatively smaller companies, interestingly, research shows that organisational growth does not need to depend on the size of the organisations (Lee, 2010). Within the enterprise growth literature, a commonly accepted claim is that it relates significantly to organisational innovation. Akman and Yilmaz (2008) suggested that innovation is an important way for companies to sustain and develop their corporate performance and maintain long-term success. Similarly, it is suggested that innovation may lead to business growth in the long run (Cho \& Pucik, 2005). Since it is well established that corporate performance relates to corporate reputation, and based on the above review on organisational legitimacy, the claim that innovation may be an important strategic tool to achieve enterprise growth gives a ground to study the complex relationships between corporate reputation, innovation legitimacy and enterprise growth. The next subsection explains the specific hypotheses of this study.

\section{Hypotheses}

Several hypotheses may be derived for testing the relationships between corporate reputation, innovation legitimacy and enterprise growth from the reviewed theoretical frameworks. The first hypothesis tests a direct relationship between corporate reputation and enterprise growth. From the RVB point of view, corporate reputation is a source of valuable and rare resources sustaining competitive advantages of organisations. Following on from this, Fombrun and Shanley (1990) argue that sound corporate reputation is positively related to expected return on investments, which may stimulate enterprise growth. Moreover, Petkova, Wadhwa, Yao and Jain (2014) indicate that a firm's reputation can increase its future performance. Taking a similar view, Gatzert (2015) evidence also that it is of high relevance between corporate reputation and corporate financial performance. We therefore put forward the first hypothesis as below:

H1: There is a positive correlation between corporate reputation and enterprise growth.

As already pointed out in the literature review, innovation is a crucial means to sustain long-term business growth. The positive relationship between innovation and business growth has been tested and proven under many different circumstances. For exam- 
ple, Eluinn (2000) suggested that innovation drives growth in outsourcing, while Grossman and Helpman (1993) claimed that innovation is an engine for growth in a global context. As legitimacy is a related concept to institutional theory which is a predominant framework in understanding corporate reputation, we hypothesise that innovation legitimacy may mediate the positive relationship between corporate reputation and enterprise growth:

H2: Innovation legitimacy has mediating effects between corporate reputation and enterprise growth.

Organisation can gains on the base of continuous innovation, product service only constantly updates to ensure to meet the public's changing needs. Also, the corporate reputation will affect people's perception of new products and services, good reputation to obtain people's identity to new products and services, such as brand effect. Public's loyalty is higher, the easier it is to accept the brand's other innovative products. Every new products /services will face the liability of newness when it enters the market, and the constraint of legitimacy is the main reason. Corporate reputation is very important for gaining innovation legitimacy, the public's loyalty to enterprise will directly affect the public's perception of products and services, and then will affect the innovation legitimacy. From the sociology perspective, to build a reputation is an effective way to obtain legitimacy. Petkova (2016) argue that new firm's reputation is significantly important to enhance legitimacy under conditions of high or extreme market uncertainty. Therefore, corporate reputation is established on base of the public's wide acceptance, Social approval is the base to obtain the innovation legitimacy.

New institutionalism theory believes, that direct cause of the high mortality of new enterprises is the lack of legitimacy, some start-up failure is due to the lack of social public trust, and not to very well solve legitimacy problem, rather than because of market constraints. enterprise growth is realised in the enterprise innovation gradually, innovation legitimacy is crucial for an enterprise to grow. Once enterprise has got innovation legitimacy, that means innovation will be accepted by government and related department, and can meet the requirements of social moral and values, and is accepted by the public. New products and services will face the new barriers to market entry. Enterprise needs to overcome the constraint of public cognitive legitimacy, and to help enterprise grow. Therefore, innovation legitimacy become the important factor for enterprise growth. High legitimacy likely win the support of stakeholders, enterprise can acquire important resources, cooperation and knowledge transfer, help enterprise accelerate to grow.

Based on these analyses, and related to $\mathrm{H} 2$ hypothesis, there are two additional hypotheses to further clarify the complex relationships between corporate reputation, innovation legitimacy and enterprise growth, so we set forth the below hypotheses for this study:

H3: Innovation legitimacy is positively related to corporate reputation.

H4: Enterprise growth is positively related to innovation legitimacy. 


\section{MATERIAL AND METHODS}

\section{Sampling}

We collected data from 191 enterprises in 16 provinces in China. In total, 300 enterprises were selected to participate in this study. Out of the 246 sets of returned questionnaires, 55 were deemed invalid and excluded from this study. Descriptive analyses showed that the valid data covered a wide range of samples in terms of enterprise types and sizes, industries, market positions and years of establishment. Among the participated enterprises, majority were from Anhui province (43\%), followed by those from Zhejiang (8\%), Guangdong (8\%), Jiangsu (7\%), Shanghai (6\%) and Beijing (6\%). Most of these respondents were from private firms (46\%) while the rest surveyed worked in state owned enterprises, including state share-holding enterprises (26\%), foreign companies (9\%) and joint ventures (6\%). Majority (55.5\%) of these companies were small-medium enterprises employing less than 500 employees, while almost half of them had less than 10 years of company history. Respondents were relatively evenly spread among over 10 broadly defined industries such as manufacturing, finance, transportation and real estate sectors. Similarly, they were also relatively evenly distributed in terms of market positions.

\section{Survey Instruments}

To contextualise survey instruments in China, we follow Li and Zhou's (2015) recent conceptual model and used their proposed survey instruments to conduct this research. Following Li and Zhou (2015), we anchored the questionnaire items of corporate reputation, enterprise growth and innovation legitimacy on a number of established and welltested measures in Western and Chinese contexts (Li \& Zhou, 2015). Corporate reputation was studied through four dimensions, including brand image, social responsibility, innovation capacity and staff quality ( 22 items in total). Innovation legitimacy was studied by regulative legitimacy, normative legitimacy and cognitive legitimacy (11 items in total). Enterprise growth was studied by six items, including performance on financial, human resources and innovation aspects. Responses were measured on a Likert scale (1 represents extremely disagree; 7 represents extremely agree).

\section{Pilot Study}

In validating measures used in this research, a preliminary study was conducted. In total, 70 samples were surveyed with a valid response rate of $96.8 \%$. Statistic testing indicated that the measures were reliable and samples were valid, i.e., values of all items were above 0.7 and KMO values were above 0.7 .

\section{Data Analysis}

We first tested the reliability of measures used in this study. The $\alpha$ values of all dimensions of corporate reputation were above 0.7 , i.e., brand image $(\alpha=0.793)$, social responsibility $(\alpha=0.857)$, innovation capability $(\alpha=0.875)$ and staff quality $(\alpha=0.929)$. The internal reliability of these dimensions was deemed sound (CITC values were above 0.4). As well, the $\alpha$ values of all dimensions of innovation legitimacy were above 0.7 , i.e., regulative legitimacy $(\alpha=0.882)$, normative legitimacy $(\alpha=0.959)$ and cognitive legiti- 
macy $(\alpha=0.916)$. All in all, the measures used in this research were deemed to be reliable. In a similar vein, KMO values indicated that the measures were sound and valid. We firstly used The Ran correlation analyses (Spearman correlation coefficients) in this research to analyse the correlation between corporate reputation (each dimension), innovation legitimacy (each dimension) and enterprise growth. But the degree of correlation analysis can verify between closely, but cannot explain the causal relationship between them. Then, we used multiple linear regression (MLR) analysis to analyse the data and path analysis was used to examine the hypotheses (Wangbin \& Yuli, 2011; Okeke, Ezeh \& Ugochukwu, 2015; Jauch, Glueck \& Osborn, 1978). The results of this research are explained in the next section.

\section{RESULTS AND DISCUSSION}

The research results suggested that, in supporting the existing literature, there were positive correlations between all dimensions of corporate reputation (i.e., brand image, social responsibility, innovation capability and staff quality) and enterprise growth. Therefore, hypothesis 1 was fully supported. Hypothesis 2 hypothesised that innovation legitimacy had mediating effects between corporate reputation and enterprise growth. Regression analysis results showed that this was partially supported. Among the possible mediating pathways, normative legitimacy mediated between brand image and enterprise growth, staff quality and enterprise growth, as well as social responsibility and enterprise growth, but did not have significant mediating effects between innovation capability and enterprise growth. Similarly, regulative legitimacy and cognitive legitimacy mediated between brand image and enterprise growth, innovation capability and enterprise growth and staff quality and enterprise growth, but did not have significant mediating effects between social responsibility and enterprise growth. In a similar vein, hypothesis 3 was also partially supported. Although there were significant positive correlations between innovation legitimacy and corporate reputation, such correlations between social responsibility and normative legitimacy, social responsibility and cognitive legitimacy and innovation capability and regulative legitimacy were not significant. On the other hand, hypothesis 4 was fully supported. There were significant positive correlations between all dimensions of innovation legitimacy and enterprise growth as tested in this research. Therefore, hypotheses 1 and 4 were fully supported whereas hypotheses 2 and 3 were partially supported (Table 1 and 2 ).

The results of this research showed that corporate reputation has significant positive relationship with enterprise growth. This positive relationship was found through all pathways tested. This means that brand image, social responsibility, innovation capability and staff quality are all important to enterprise growth. Similar effects were found for innovation legitimacy on enterprise growth, indicating that legitimacy is an important theoretical perspective in understanding how businesses could develop in various important aspects. Although the mediating role of innovation legitimacy between corporate reputation and enterprise growth was only partially supported, most pathways showed significant mediating effects of innovation legitimacy between the two variables. The results of this research imply that legitimacy is a fruitful theoretical framework in 
understanding the positive correlation between corporate reputation and enterprise growth.

Table 1. Descriptive Statistics and Correlations $(n=191)$

\begin{tabular}{|c|c|c|c|c|c|c|c|c|c|c|}
\hline Variables $^{\mathrm{a}}$ & mean & SD & $\mathbf{1}$ & $\mathbf{2}$ & $\mathbf{3}$ & $\mathbf{4}$ & $\mathbf{5}$ & $\mathbf{6}$ & $\mathbf{7}$ & $\mathbf{8}$ \\
\hline $1 \mathrm{BI}$ & 4.954 & 1.384 & 1 & & & & & & & \\
\hline $2 \mathrm{SR}$ & 4.542 & 1.524 & $0.402^{* *}$ & 1 & & & & & & \\
\hline $3 \mathrm{IC}$ & 4.951 & 1.397 & $0.632^{* *}$ & $0.501^{* *}$ & 1 & & & & & \\
\hline $4 \mathrm{SQ}$ & 5.068 & 1.236 & $0.326^{* *}$ & $0.411^{* *}$ & $0.206^{* *}$ & 1 & & & & \\
\hline $5 \mathrm{RL}$ & 4.956 & 1.472 & $0.603^{* *}$ & $0.478^{* *}$ & $0.432^{* *}$ & $0.413^{* *}$ & 1 & & & \\
\hline $6 \mathrm{NL}$ & 5.181 & 1.226 & $0.557^{* *}$ & $0.212^{* *}$ & $0.598^{* *}$ & $0.504^{* *}$ & $0.610^{* *}$ & 1 & & \\
\hline $7 \mathrm{CL}$ & 5.091 & 1.128 & $0.512^{* *}$ & $0.204^{*}$ & $0.509^{* *}$ & $0.477^{* *}$ & $0.597^{* *}$ & $0.754^{* *}$ & 1 & \\
\hline $8 \mathrm{EG}$ & 4.727 & 1.282 & $0.549^{* *}$ & $0.503^{* *}$ & $0.551^{* *}$ & $0.429^{* *}$ & $0.712^{* *}$ & $0.686^{* *}$ & $0.736^{* *}$ & 1 \\
\hline
\end{tabular}

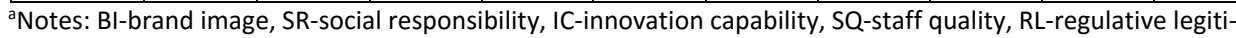
macy, NL- normative legitimacy, CL-cognitive legitimacy, EG-enterprise growth.

Source: own study based on survey data in China.

Table 2. Multiple Linear Regression

\begin{tabular}{|c|c|c|c|c|c|c|c|c|}
\hline Variables $^{b}$ & $\begin{array}{c}\text { Model1 } \\
\text { (EG) }\end{array}$ & $\begin{array}{c}\text { Model2 } \\
\text { (RL) }\end{array}$ & $\begin{array}{c}\text { Model3 } \\
\text { (NL) }\end{array}$ & $\begin{array}{l}\text { Model4 } \\
\text { (CL) }\end{array}$ & $\begin{array}{c}\text { Model5 } \\
\text { (EG) }\end{array}$ & $\begin{array}{l}\text { Model6 } \\
\text { (RL } \\
\text { mediate } \\
\text { CR\&EG) }\end{array}$ & $\begin{array}{l}\text { Model7 } \\
\text { (NL } \\
\text { mediate } \\
\text { CR\&EG) }\end{array}$ & $\begin{array}{c}\text { Model8 } \\
\text { (CL } \\
\text { mediate } \\
\text { CR\&EG) }\end{array}$ \\
\hline CONS & $1.352 * * *$ & $1.273 * * *$ & $1.045^{* * *}$ & $1.453^{* * *}$ & $1.521^{* * *}$ & $2.186 * * *$ & $2.351 * * *$ & $2.068 * * *$ \\
\hline $\mathrm{BI}$ & $0.185^{*}$ & $0.362 * * *$ & $0.222 * *$ & $0.207 * *$ & - & $0.125^{+}$ & $0.151^{*}$ & $0.134^{*}$ \\
\hline SR & $0.262^{* * *}$ & $0.269 * * *$ & 0.014 & 0.016 & - & $0.203^{* * *}$ & $0.171^{*}$ & $0.177^{* *}$ \\
\hline IC & $0.210^{* *}$ & 0.029 & $0.340 * * *$ & $0.249 * * *$ & - & $0.189 * * *$ & $0.134^{*}$ & $0.101^{+}$ \\
\hline SQ & $0.269 * * *$ & $0.222^{* * *}$ & $0.279 * * *$ & $0.295^{* * *}$ & - & $0.412 * * *$ & $0.261 * * *$ & $0.469 * * *$ \\
\hline $\mathrm{RL}$ & - & - & - & - & $0.357^{* * *}$ & - & - & - \\
\hline $\mathrm{NL}$ & - & - & - & - & $0.154^{*}$ & - & - & - \\
\hline $\mathrm{CL}$ & - & - & - & - & $0.358 * * *$ & - & - & - \\
\hline Adj-R ${ }^{2}$ & 0.376 & 0.327 & 0.379 & 0.317 & 0.536 & - & - & - \\
\hline $\mathrm{F}$ & 29.583 & 29.082 & 29.918 & 21.559 & 74.018 & 40.426 & 33.359 & 43.578 \\
\hline
\end{tabular}

${ }^{b}$ Notes: BI-brand image, SR-social responsibility, IC-innovation capability, SQ-staff quality, RL-regulative legitimacy, NL- normative legitimacy, CL-cognitive legitimacy, EG-enterprise growth.

Source: own study based on survey data in China.

Our study shows that there are significant positive relationships between brand image, social responsibility, innovation capability, staff quality, and enterprise growth. These Indicate that the higher corporate reputation, enterprise will obtain the greater opportunities of growth. Similar to Dowling and Pfeffer (2002) found that corporate reputation, being enterprise important strategic asset, has important effect to corporate performance. Enterprise with good reputation, can hasve a high position in the customer heart, gain customer loyalty, use intangible assets to build enterprise core competitive capability, to promote enterprise sustainable development.

Also this study found there partly exists a correlation between organisation reputation and innovation legitimacy. Similar to Dacin, Oliver and Roy (2007) it can be pointed out that entrepreneurial team reputation plays an important role in gaining the legitimacy of start-up. Brand image is helpful to make new products more accepted by government and professional institutes, and can be widely accepted by the customers, which 
implies that the new product is in accordance with the public ethics and value. Our empirical research shows that the higher enterprise obtains innovation legitimacy, the better enterprise grows. Legitimacy is helpful to improve the growth performance of small and medium-sized enterprise. Enterprise's new product, which has higher innovation legitimacy, will be known and accepted by government departments, professional institutions and the public. Conforming to social values and moral standards facilitates sustainable development of enterprise.

\section{CONCLUSIONS}

\section{Main Conclusions, Implications and Recommendations for Practice}

Corporate reputation has a positive influence on enterprise growth. Brand image is useful to introduce innovative products into markets, and at the same time high reputation shows that the value of organisation is in keeping with social values, and meets social morality. That kind of organization can make the enterprise innovative products known and accepted by the public, which means that the enterprise has obtained innovation legitimacy, that can promote enterprise growth. Innovation capability can help enterprise integrate and utilise innovation resources, good corporate reputation is helpful to the development of enterprise innovation behaviour. So enterprise should pay attention to the maintenance of brand image, to be responsible for products, customers, shareholders and employees. And to be able to find new market demand, to raise their ability to innovate, to follow the principle of being people-oriented, to attract more qualified talents to join, in order to realize the sustainable growth of enterprise.

Innovation legitimacy plays an important role in the enterprise growth process. Enterprise growth must depend on innovation, and innovation legitimacy has become the important influence factor of enterprise innovation to be realised. Regression analysis shows that there is a significant correlation between normative legitimacy, regulative legitimacy, cognitive legitimacy, and enterprise growth. At the same time, regulative legitimacy, normative legitimacy, cognitive legitimacy, has a mediating effects between corporate reputation and enterprise growth. This suggests that good corporate reputation can help enterprises obtain customer resources, the accumulation of customer resources can promote enterprise technology innovation. Good corporate reputation can bring high customer loyalty for a long time, thus greatly reduce the time of the innovation product accepted by market, innovative products can more quickly overcome the entering defect of the market.

There are significantly positive relationships between Innovation legitimacy and corporate reputation of brand image, staff quality. Moreover, corporate reputation of social responsibility is significantly related to regulative legitimacy, innovation capability is positively related to normative legitimacy and cognitive legitimacy. This suggests that it is particularly important for enterprises in lack of regulative legitimacy, to strengthen brand imagine maintenance, and social responsibility, and to improve staff quality. When an enterprise lacks normative legitimacy and cognitive legitimacy, it is important for enterprise to enhance the corporate reputation of brand image, innovation capability, and staff quality. In case of lack of innovation legitimacy enterprise may take steps to 
obtain in accordance with the different correlation of each dimension of corporate reputation.

\section{Limitation and Future Research Direction}

This research was conducted in Chinese context and its measures were highly contextualised. Although the reliability and validity of these measures were tested to be acceptable, the generalisability of the results in other societal contexts may not be granted. This is especially worthy of attention as legitimacy is a cultural product. Future research is encouraged to further pursue the theoretical framework of legitimacy in understanding enterprise growth, corporate reputation and their relationships. The generalisability of the research results may be further tested in Western contexts in the future.

This research studied the mediating effects of innovation legitimacy between corporate reputation and enterprise growth. Its results suggested that innovation legitimacy significantly mediated the positive relationship between the other two variables. In supporting the existing literature, positive correlations between corporate reputation and enterprise, and innovation legitimacy and enterprise growth were also found. Future research may look into these results in other contexts and further pursue the legitimacy perspective in understanding corporate reputation and enterprise growth.

\section{REFERENCES}

Akman, G., \& Yilmaz, C. (2008). Innovative capability, innovation strategy and market orientation: an empirical analysis in Turkish software industry. International Journal of Innovation Management, 12(1), 69-111.

Aldrich, H.E., \& Fiol, C.M. (1994). Fools rush in? The institutional context of industry creation. Academy of Management Review, 19, 645-670.

Petkova, A.P. (2016). Standing Out or Blending In? The Formation of New Firms' Legitimacy and Reputation under Different Levels of Market Uncertainty. Corporate Reputation Review, 19(1), 22-34.

Petkova, A.P., Wadhwa, A., Yao, X., \& Jain, S. (2014). Reputation and Decision under Ambiguity: A Study of U.S. Venture Capital Firms, Investments in the Emerging Clean Energy Sector. Academy of Management Journal, 57(2), 422-448.

Barney, J. (1991). Firm resources and sustained competitive advantage. Journal of management, 17(1), 99-120.

Basdeo, D.K., Smith, K.G., Grimm, C.M., Rindova, V.P., \& Derfus, P.J. (2006). The impact of market actions on firm reputation. Strategic Management Journal, 27, 1205-1219.

Cable, D.M., \& Graham, M.E. (2000). The determinants of job seekers' reputation perceptions. Journal of Organizational Behavior, 21(8), 929-947.

Carmeli, A., \& Tishler, A. (2005). Perceived organizational reputation and organizational performance: An empirical investigation of industrial enterprises. Corporate Reputation Review, 8(1), 13-30.

Cho, H.J., \& Pucik, V. (2005). Relationship between innovativeness, quality, growth, profitability, and market value. Strategic Management Journal, 26(6), 555-575.

Dacin, M.T., Oliver, C., \& Roy, J. (2007). The legitimacy of strategic alliances: an institutional perspective. Strategic Management Journal, 28(2), 169-187. 
Deephouse, D.L. (2000). Media reputation as a strategic resource: An integration of mass communication and resource-based theories. Journal of Management, 26(6), 1091-1112.

Dowling, J.E., \& Pfeffer, J. (1975). Organizational legitimacy: Social values and organizational behavior. Pacific Sociological Review, 18, 122-136.

Eluinn, J.B. (2000). Outsourcing innovation: the new engine of growth. Sloan Management Review, 41(4), 13-28.

Fang, L.H. (2005). Investment bank reputation and the price and quality of underwriting services'. The Journal of Finance, 60(6), 2729-2761.

Flanagan, D.J., \& O'Shaughnessy, K.C. (2005). The effect of layoffs on firm reputation. Journal of Management, 31(3), 445-463.

Fombrun, C., \& Shanley, M. (1990). What's in a name? Reputation building and corporate strategy. Academy Of Management Journal, 33(2), 233-258.

Gibson, D., Gonzales, J.L., \& Castanon, J. (2006). The importance of reputation and the role of public relations. Public Relations Quarterly, 51(3), 15-18.

Grossman, G.M., \& Helpman, E. (1993). Innovation and growth in the global economy. MIT press. Retrieved on April 30, 2016 from https://mitpress.mit.edu/books/innovation-and-growthglobal-economy

Hall, R. (1993). A framework linking intangible resources and capabilities to sustainable competitive advantage. Strategic Management Journal, 14(8), 607-618.

Jauch, L.R., Glueck, W.F., Osborn, R.N. (1978). Organizational Loyalty, Professional Commitment, and Academic Research Productivity. Academy of Management, 21(1), 84-92.

Jepperson, R.L. (1991). Institutions, institutional effects, and institutionalism. In W.W. Powell, \& P.J. DiMaggio (Eds.), The new institutionalism in organizational analysis: (pp. 143-163). Chicago: University of Chicago Press.

Lee, C.Y. (2010). A theory of firm growth learning capability, knowledge threshold, and patterns of growth. Research Policy, 39(2), 278-289.

Li, H.G., \& Zhou, J. (2015). Organization reputation and enterprise growth: the mediating role of innovation legitimacy. Science \& Technology Progress and Policy, 32(10), 84-87.

Milgrom, P., \& Roberts, J. (1982). Predation, reputation, and entry deterrence. Journal of Economic Theory, 27, 280-312.

Gatzert, N. (2015). The impact of corporate reputation and reputation damaging events on financial performance: Empirical evidence from the literature. European Management Journal, 33(6), 485-499.

Okeke, T.C., Ezeh, G.A., \& Ugochukwu, N.O.A. (2015). Service Quality Dimensions and Customer Satisfaction with Online Services of Nigerian Banks. Journal of Internet Banking and Commerce, 20(3).

Olson, M. (1965). The logic of collective action. Cambridge, MA: Harvard University Press.

Parsons, T. (1960). Structure and process in modem societies. Glencoe, IL: Free Press.

Pfeffer, J. (1981). Management as symbolic action: The creation and maintenance of organizational paradigms. In L.L. Cummings, \& B.M. Staw (Eds.), Research in organizational behavior: an annual series of analytical essays and critical reviews (pp. 1-52). Amsterdam: Elsevier.

Rindova, V.P., Williamson, I.O., Petkova, A.P., \& Sever, J.M. (2005). Being good or being known: An empirical examination of the dimensions, antecedents, and consequences of organizational reputation. Academy of Management Journal, 48(6), 1033-1049. 
Scott, W.R., \& Meyer, J.W. (1991). The organization of societal sectors. In W. W. Powell, \& P.J. DiMaggio (Eds.), The new institutionalism in organizational analysis (pp. 108-140). Chicago: University of Chicago Press.

Suchman, M.C. (1995). Managing legitimacy: Strategic and institutional approaches. Academy of Management Review, 20(3), 571-610.

Turban, D.B., \& Greening, D.W. (1997). Corporate social performance and organizational attractiveness to prospective employees. Academy of Management Journal, 40, 658-672.

Walker, K. (2010). A systematic review of the corporate reputation literature: definition, measurement, and theory. Corporate Reputation Review, 12(4), 357-387.

Wangbin, H., \& Yuli, Z. (2011). New Venture Capability of the Transformation from Entrepreneurial Orientation to the New Venture Performance: A Theory Model and Empirical Study in China. Nankai Business Rivew, 14(1), 83-95.

Zucker, L.G. (1986). Production of trust: Institutional sources of economic structure, 1840-1920. Research in Organizational Behavior, 8, 53-111. 


\section{Authors}

Contribution share among the authors is as follows: Honggui G. Li - 60\% (Conceptual model, research design, data collection, interpretation of data and analysis); Zhongwei W. Chen $-20 \%$ (methodology); Guoxin X. Ma-20\% (literature review).

\section{Honggui G. Li}

Dr. Honggui G. Li is an Associate Professor at School of Business Administration, Anhui University of Finance \& Economics (China). Dr. Li is a core member and the secretary of the university's Research Centre of Entrepreneurship and Enterprise Growth. He is also a member of IACMR and a director of Anhui Behavioural Science Association.

Correspondence to: Dr Honggui G. Li; School of Business Administration, Anhui University of Finance \& Economics; Bengbu 233030, Anhui, China; e-mail: Lihonggui0812@163.com

\section{Zhongwei W. Chen}

Dr. Zhongwei W. Chen is a Professor at School of Business Administration, Anhui University of Finance \& Economics (China). He is currently a Vice President of the university and in charge of its research Centre of Entrepreneurship and Enterprise Growth. Prof Chen is also on the board of the Ministry of Education's Advisory Committee of Teaching Undergraduates in Business Administration and a visiting professor of four other Chinese universities.

Correspondence to: Dr. Zhongwei W. Chen; School of Business Administration, Anhui University of Finance \& Economics; Bengbu 233030, Anhui, China; e-mail: czwancai@126.com

\section{Guoxin X. Ma}

Guoxin X. Ma is a PhD researcher at Hull University Business School (UK). She worked as a visiting scholar at School of Business Administration, Anhui University of Finance \& Economics (China), at the time of this research.

Correspondence to: Guoxin X. Ma; e-mail: mgxb1314@163.com

\section{Copyright and License}

This article is published under the terms of the Creative Commons Attribution - NonCommercial - NoDerivs (CC BY-NC-ND 3.0) License http://creativecommons.org/licenses/by-nc-nd/3.0/ 
